David Whittier; Sonia Lara (2006). Preparing Tomorrow's Teachers to Use Technology (PT3) at Boston University through Faculty Development: Assessment of Three Years of the Project. Technology, Pedagogy and Education Vol. 15, No. 3 (pp. 321-335) [http://www.tandfonline.com/doi/abs/10.1080/14759390600923816\#.VBk9TdfAGSo]

\title{
Preparing Tomorrow's Teachers to Use Technology (PT3) at Boston University through Faculty Development Assessment of Three Years of the Project
}

\author{
David Whittier \\ Assistant Professor \\ Director, Instructional Materials Center \\ School of Education Boston University USA \\ <whittier@bu.edu> \\ Sonia Lara \\ Assistant Professor \\ School of Humanities and Social Sciences \\ Department of Education. University of Navarra. SPAIN \\ <slara@unav.es>
}

\begin{abstract}
The Boston University PT3 grant project proposed first to train faculty to use technology and then to sustain the gained expertise in a curriculum development project. Education faculty gains in integrating technology into their teaching and their modeling of that use were clearly demonstrated in phase one of the project (the initial two years of the project). In phase two (the third year), faculty were challenged to produce innovate, interdisciplinary curriculum development projects investigating judgment in their discipline. Prototypes of the Judgment Curriculum (JC) produced in phase two of the project demonstrate an intersection of technology competence and innovative, question driven instruction. Preliminary data show strong gains in faculty use of technology in their teaching and in faculty requirements that their students use technology in education coursework. However, continued development of the Judgment Curriculum lessons remains a challenge.
\end{abstract}

The Nature of the contribution: Scholarly article, 6.432 words.

\section{Introduction}

Preparing educators to use new technologies in service to identified pedagogical objectives is a major challenge for $21^{\text {st }}$ century education. UNESCO illustrates the global nature of this point in their 1998 World Education Report, Teachers and Teaching in a Changing World. They highlight a problem in educational use of technology in stating that, "educational systems around the world are under increasing pressure to use the new information and communication technologies (ICTs) to teach students the knowledge and skills they need in the 21st century." While this statement refers to what students need to learn, the report goes on to conclude that "the radical implications ICTs have for conventional teaching and learning [...] predicts the transformation of the teaching-learning process and the way teachers and learners gain access to knowledge and information. [...] Teacher education institutions and programmes must provide the leadership for pre- and in-service teachers and model the new pedagogies and tools for learning." (UNESCO, 2002:3). Here there is an emphasis on access to information but it does not address the question "access to what?" Distinguishing between harnessing new technology to meaningful learning objectives rather than 
modifying those objectives to accommodate the capabilities and limitations of technology, is one of the many challenges associated with the transformations generated through new technology. Emphasizing learning objectives driven technology integration suggests a timeless emphasis on pedagogy and the complex need to harness our rich technologies of today to what we decide is worth learning.

This paper reports on an effort at the Boston University School of Education to improve both teacher education faculty and teacher candidates ability to use technology in support of learning objectives through a US DOE PT3 grant begun in 2001 and completed in 2005. It reports a largely successful program to improve education faculty's use of technology in their own teaching and their receptivity to their students' use of technology in the first phase of the grant. It also reports largely unsuccessful attempts to sustain these gains after the completion of the grant through the creation of an innovative curriculum project called the Judgment Curriculum. As such it suggest both strategies worthy of adoption as well as strategies that need further refinement for projects focusing on faculty development in the use of technology. First, however, we wish to set the Boston University project in an international perspective.

Globally, the efforts to integrate ICT and the results therefore, vary widely. The degree of integration of ICTs is very different in North America, Asia, Europe, South America, Africa and the Australian Pacific region (Education Week, 2004: vol23, number35; Kozma, 2003). For example, the number of students per computer at the schools varies from five in US to 123 in South Africa. The percent of school computers connected to the Internet in Australia is 80 and in Singapore 25. The challenge in the US and the more advanced countries in Europe is how to use ICT in the school: "Most teachers have basic [technology] skills; but the next question is integration in their practice, in their subject areas" (Education Week, 2004). The global picture then is staggered as usual: while many teachers in developed Western countries are focusing on improving the integration of technology, most nations in Africa are decades behind where one of the biggest obstacles is simply a lack of sufficient infrastructure, such as phone lines and electricity.

Despite the enormous growth in technology infrastructure in education in the developed countries, research tells us that the path to effectively using all the technology now in schools to improve learning is complex and circuitous. Cuban (2001) and Becker's (2000) special report document particularly well how difficult and complex it is for teachers and professors to improve learning with technology. These works also draw distinctions between using technology for personal productivity, administrative tasks, research, and communication on the one hand, and using it for instruction and assessment on the other. They also point out that a major obstacle in taking advantage of this new expensive infrastructure was, and is, the lack of money and time put toward teacher training and, once teachers do have the expertise and the requisite technology, giving them time to develop resources that fit perfectly into their classrooms and curricula.

Partly in response to awareness of this deficit several initiatives for training teachers emerged in different countries around the world (cfr. UNESCO, 2002, 2003, 2005). Project InTent was the first national initiative to integrate ICTs into pre-service teacher education. It took place in England between 1989 and 1992, following increasing pressure to prepare teachers before they started practicing in schools (Davis, Kirkman, Tearle, Taylor, \& Wright, 1996). The US Congress approved in 1999 the program for Preparing Tomorrow's Teachers to use Technology (PT3) which addressed a similar objective. The SchoolNet programme, in South Africa, was established to support educational renewal in some the most challenged schools in the country and to "create learning communities of educators and learners who use information and communication technologies (ICTs) to enhance education in South Africa” (http://www.school.za/about/more_about.htm, n. d.). The Enlaces Program, in Chile, trained teachers and provided them with technical and educational support. The majority of participating ICT-using teacher educators in Enalces were drawn from 24 universities, which became known as the Technical Assistance Network (Hinostroza, Hepp, \& Laval, n. d.; Potashnik, 1996).

In the case of US the evolving power of computing technology, the growth of the Internet, and the implementation and use of the WWW have stimulated in the last decade a substantial investment in 
hardware, software, infrastructure, training, and support at all levels of education, but especially in k12 schools and higher education. Numerous reports have documented the massive and historic growth of technology in education (CEO, 1997, 1999, 2000a, 2000b, 2001; OTA, 1995; WBEC, 2000; The Technology Counts series by Education Week, 1997-1999, 2001, 2002, 2003, 2004, 2005, Campus Computing Project, 1995-2003). The main project for training teachers in US has been PT3 Program. A major emphasis of PT3 was to correct the under-funding of teacher training evident in finding that only $14 \%$ of the $\$ 5.5$ billion spent on technology related issues in the 1998-99 academic year was devoted to staff development. The PT3 web site "21st Century Learners: The Need for Tech-Savvy Teachers" (http://www.pt3.org/technology/21century_learners.html) reports that only "33 percent of teachers feel well prepared to use computers and the Internet for a variety of potential uses in their teaching." Adding to that is the finding "that only 44 percent of new teachers (three or fewer years in the classroom) feel well-prepared to use technology" (Rowand, 2000). PT3 was in part created to remedy this poor preparation by focusing on funding teacher training and faculty development projects. The program aimed to "break the cycle that leaves new teachers unprepared to use modern learning technologies because their education professors weren't modeling appropriate technology use" (http://www.pt3.org/technology/21century_learners.html).

\section{Preparing Tomorrow's Teachers to use Technology at Boston University (BU-PT3)}

In July 2001, the United States Department of Education (US-DOE) awarded Boston University School of Education faculty a three-year grant to improve the preparation of new teachers to use technology. Titled Preparing Tomorrow's Teachers to use Technology at Boston University, the BUPT3 grant project had two principle aims (Whittier \& Steiner, 2001). First, the infusion of high quality educational technology into all aspects of the School of Education's (SED's) teacher preparation programs, and second, to sustain the infusion of educational technology achieved during the grant period beyond the withdrawal of funding at the end of the grant. To facilitate achieving these goals, each one had a subset of carefully sequenced and progressive objectives, each objective building on the one before (see Table I).

[Insert Table I]

This paper reports the thinking from which our goals and objectives were derived, our methodologies for achieving them, and the progress made during the first two years and last third year of the grant.

\section{First Phase: years 2001-2002 and 2002-2003}

\section{Goals and Methodology in Faculty Development}

The methodology for achieving the first aim was to prepare tomorrow's teachers to use technology by improving faculty expertise in using technology in their teaching and consequently, their modeling of its use in support of teaching and learning.

The project focused on faculty development through reasoning that the faculty model good teaching and if they did not use technology effectively, how could they prepare their students -tomorrow's teachers- to do so? This was a critical first step made with the thinking that any hope of sustaining the use of technology would be dependent on first involving our faculty in using it effectively in their teaching. Guidance in designing the program for generating this involvement came from historical studies of how teachers have used technology, particularly from the work of Cuban $(1986,2001)$ and Saettler (1990). The mission adopted for the grant was that faculty would adopt technology to the extent that it helped them improve their teaching and their students learning. Cuban's finding that "teachers have altered their practice when a technological innovation helped them do a better job of 
what they already decided had to be done and matched their view of daily classroom realities" guided this thinking (Cuban, 1986, p. 66).

The first major decision was choosing to train the 10 participating SED faculty in the use of an early version of Blackboard's web-based course support system called "Courselnfo" (Cl) (http://www.blackboard.com/). A December 2000 survey of participating faculty showed that they had little or no knowledge of this type of software and project staff thought $\mathrm{Cl}$ was relatively easy to learn. Courselnfo also could serve as a limited electronic portfolio for more specialized resources made with PowerPoint and digital video. This decision framed all the other selections we made in the faculty development program.

\section{Goals and Plans for Year 1 and 2: The Faculty Training Program}

Three elements comprised the BU-PT3 faculty training program:

First was instruction in web tools software so that faculty would start using the web, which goes far toward solving key problems of ease of access and ease of revision historically related to ineffective use of technology in education. This instruction began with Courselnfo, and, once all faculty had Courselnfo web sites, continued with instruction in other software such as Power Point and iMovie. All instructional sessions were focused on producing digital resources for the participating faculty's own courses and we devoted substantial time to introducing and discussing web-based pedagogies such as those described in the Filamentality program (http://www.kn.pacbell.com/wired/fil/).

Second was a critical component of support for the faculty development program delivered by four graduate students who served as the Educational Technology Group (ETG). All were experienced educational technologists and able to tutor the faculty in the software as well as consult with them on pedagogical issues. The ETG attended all training sessions and met individually with the faculty in their offices to assist them in applying the instruction of the session to their own courses. The ETG were instructed not to do the work for the faculty but rather, to help them "do it themselves."

Third was a series of formal training sessions and roundtables. The training was comprised of twohour instructional sessions designed to build the competence of participating faculty in applying computer and Internet technologies to their particular disciplines and courses. The meetings included discussion of how the application at hand would affect teaching and learning and these discussions kept our work focused on education and prevented faculty from becoming overwhelmed with learning technology. The roundtables, where everyone shared the resources produced through the grant, came at the end of each year. They were useful in encouraging the faculty to develop their resources well enough to be comfortable sharing them with their colleagues. They also nurtured our community of learners through providing a context for sharing ideas and strategies.

Perhaps the most significant learning in the first two years was the idea that despite the necessity of instruction in using technology, the pedagogical advantages of employing technology needed to be the focus, not the technology itself (Whittier \& Lara, 2003a, 2003b). In nearly every case, faculty wanted to learn those software skills that would help their students to achieve their learning objectives. Aside from brief introductions, software per se was not taught, instead, faculty were taught what they needed to know to produce what would be useful in their teaching. This led to coining the phrase: Learning Objectives Driven Software Instruction or, LODSI, to describe this type of contextualized software instruction.

\section{Results of External Evaluation}

The project's external evaluator reported on the following points at the end of the first year:

- Faculty engagement: Faculty were most engaged in training sessions where they were given opportunities to use technology in ways immediately applicable to their professional lives or where they were learning about K-12 instructional uses of technology.

- Faculty learning: Faculty learned not only how to use specific technologies in their instruction but also reflected on the appropriateness of those uses. 
- Faculty roundtable: All had used Courselnfo $(\mathrm{Cl})$, the majority for the first time, and had posted to their $\mathrm{Cl}$ web site updated syllabi reflecting their new technology expertise, assignments, surveys, and class notes. Most had also used PowerPoint and digital video clips with instructional framing, and a few had constructed web-based learning activities.

- ETG: The ETGs provided hands-on technical assistance during and between training sessions and worked with faculty around establishing Courselnfo sites for their courses. (External evaluator, TERC, 2003)

Faculty improvement in the use of technology was even more evident after the second roundtable at the end of 2002-2003. For example, the external evaluator wrote: "The five faculty who presented at this session were using technology in far more sophisticated and complex ways than they had done the previous school year... This year the faculty demonstrations included Web Quests, uses of the discussion board feature of the Courselnfo site, successful and "problem-free" online assignments, and required student use of technology curricula like art education methods and physical education methods.

After completing two years of faculty development, the external evaluator asked the faculty to respond to the question: In general, how would you compare your technology use now with your use last year? The summary of answers to this question conclude that the faculty:

- Could do more technologically than they could last year;

- Could converse with their students more knowledgeably about technology;

- Were more deliberate in their pedagogical use of technology;

- Had discovered the value of the management tools now available to them.

\section{Second Phase: year 2003-2004}

\section{Goals for Year 3: The Judgment Curriculum}

Year 3 began a new phase of the project: producing a web-based curriculum on issues of judgment. From a content perspective, the Judgment Curriculum (JC) project aimed to highlight historical and contemporary issues of judgment in and across traditional school subject matter disciplines and in teacher preparation. Teaching and learning about judgments is a complex domain and far more complex than can be addressed here, as the purpose of this article is to begin investigating the efficacy of curriculum development as a method of sustaining faculty expertise in teaching with technology. Although the project provides material to report much more about teaching, learning about, and exercising judgment in the future, the aim initially was to introduce the strategy of involving both participating faculty and their students in developing, testing, and utilizing technologybased resources not only to teach their disciplines but also to develop their judgment. Thus, from a faculty development perspective, the $\mathrm{JC}$ provided a forum for faculty and students to sustain and elaborate their ability to effectively employ technology in education.

The content of the JC was conceptualized as including issues of judgment in all the disciplines as well as pedagogy and teacher preparation. From its inception, the JC was intended to stimulate the study of and practice of making judgments for both teachers and students. The JC was described as focusing on "strengthening the skills of discernment, probing understanding, and critical thinking in the context of demanding academic content" (Whittier \& Steiner, 2001). Organized in a questiondriven format, the JC requires both its users and its authors to exercise judgment in teacher preparation in all subject areas and grade levels. However, as the various projects took shape, it became clear that judgment means different things to different people. While allowing that there may be different methods of judgment, judgment was defined negatively as "not a calculation" and furthermore, for purposes of the grant, it was defined positively as focusing on careful research and the weighing of evidence (Weizenbaum, 1976). However, beyond those general guidelines, project directors left open the meaning and definition of judgment as a concept inviting interpretation. The BU-PT3 community of learners participating in the grant project were challenged to propose and discuss what constitutes judgment in a kind of collective greenhouse for nurturing faculty ideas on lessons and units that emphasize judgments. 
The BU-PT3 grant gave participating SED faculty badly needed opportunities for learning to integrate educational technology into their teacher preparation courses. Having achieved reasonable success in doing that (Whittier \& Lara, 2003a, 2003b), the Judgment Curriculum presents our faculty and their students the opportunity of an ongoing task that will solidify their technology skills in a projectbased, learning-by-doing environment. However, there are important questions beginning with how effective the $\mathrm{JC}$ will be in sustaining faculty gains in using technology, in better preparing tomorrow's teachers to use technology, and ultimately, in improving student learning? This paper begins to address these questions.

\section{Methodology}

The process of developing the Judgment Curriculum built on the training the School of Education (SED) faculty received in the first two years of the grant. The plan was that as faculty gained expertise in using technology to improve teaching and learning, and then in turn modeled the use of technology-based resources, they would involve their students, tomorrow's teachers, in coauthoring and testing the use of the Judgment Curriculum in their methods courses and student teaching. Our numbers of participating faculty in the grant were small. We started with 10 but during phase one, three left the project as one accepted a new job outside the university, another won a large grant and no longer had time, and a third landed a textbook contract and had to concentrate on that. We were able to add one new faculty in the middle of phase one but it was rather surprising that it was not easy to add in new faculty once the project was underway. When we began phase two, however, there were eight committed faculty and both project directors were also working on JC lessons, bringing the total to 10 possible projects. Of those 10 , eight were able to conceive and produce, with the help of the ETG, their JC projects during phase two. Although experience with these projects to date is limited, students have participated in three of eight curriculum projects, and while that is less than anticipated, it is a start.

While students have had limited involvement, producing a JC lesson did spark faculty collaboration in examining and wrestling with the meaning of judgment and how to study that meaning in each subject. The task of building these lessons has given SED faculty, their ETG collaborators, and in some cases, their students, a unique opportunity to update their skills in a context driven by a pedagogical imperative, rather than a technological one.

The proposal for the BU-PT3 grant project stated that "the Judgment Curriculum will be designed unit by unit by our faculty and their students, tomorrow's teachers, as a Web-based curriculum for schools integrated across the humanities, arts, social and natural sciences" (Whittier \& Steiner, 2001). This promise has largely come to fruition as we now have projects in most of these areas. The projects to date, and their discipline areas, include: What is Violence in Children's Writing? (Elementary Education), Is the Individual a Myth? (Science Education), US Elections: Democratic Enough? (History/Social Science), Accommodations versus Modifications: How are they Different? (Special Education), How do we value competitive versus cooperative games? (Physical Education), What is Truth in Shakespeare's King Lear? (English Education), and What is Technology? (Technology/Science/Engineering Education).

The BU-PT3 proposal also stated that, "the curriculum will be focused on providing school children with multiple opportunities to learn the skills of discernment, careful evaluation, and critical thinking in an academically demanding intellectual environment" (Whittier \& Steiner, 2001). This has turned out to be less true as most of the projects focus on training pre-service and/or in-service teachers rather than on "school children" per se. Although this suggests that the concept was off target with respect to intended users, the qualities of careful evaluation and critical thinking are prominent in the projects underway. The difference is that it is pre-service and in-service teachers who are exercising judgment through these curriculum projects and not k-12 students - at least so far. It is possible that going forward, the students of our faculty will begin developing resources to use with $k-12$ students. However, one of the lessons learned so far is that this is much more difficult and time consuming than anticipated. 
The BU-PT3 project formally ended June 30, 2005, after a US DOE approved one-year "no-cost extension" during 2004-2005. During the extension year, and the fall of 2005, faculty use of judgment curriculum lessons developed as part of the grant varied. No progress was made toward a more generally distributable curriculum project but most faculty continued to use and refine their JC resources as part of their teaching. For example, after using her JC project in teaching during the spring of 2005, one faculty reported that her students found the project "boring," and consequently she did not use it in fall 2005. She contacted the project director in hopes of finding a skilled graduate student to help her revise it into a more "dynamic" format because she wants to continue to use it. However, without money to pay such a graduate student, no volunteer came forward and the project was shelved for another semester. We are now looking for another small grant to help revise the project for more productive deployment. Another faculty reported that he had used his JC unit with students in spring 2005, but not in fall 2005. He reported that he thinks the lesson itself is good but "it needs a more secure place in my curriculum." He indicated that it was difficult to shift the focus of his instruction from content per se to judgment about the meaning of the content.

Another faculty reported that she liked very much the work she had done on her JC unit but that it needed further development and she was stymied by a lack of time and skilled support of the type previously offered by the ETG. Another faculty reported that she and a doctoral student had continued to develop the work begun as part of the JC turning it into an online tutorial. The doctoral student is now conducting a pilot study to test the effectiveness of the tutorial and if it "accomplishes what we want it to, we hope to phase it into regular course work." Another doctoral student who had worked with a participating faculty member in developing a JC unit and who in 2005 was working as a teaching fellow in a methods course reported more extensive use of the JC unit.

We use the Democracy Unit as a model for CT 575 (a secondary methods course taught just prior to student teaching). We show it to beginning/pre-service teachers (undergrads/masters) as a model on several levels: one is to showcase the creative use of tech resources. Another is the idea that content can/should be presented/absorbed in multiple formats (image, sound, text). Another focus is on how to develop/use good questions in lesson plans and units. The unit is presented prior to the students doing their own group unit ... It sits online ... all term for their referral (Personal Communication, 2005).

As the faculty and doctoral student reports indicate, some continued to work on developing and revising the JC lessons begun in the context of the grant, while others appeared to be slipping into dormancy. All of the continuing work, however, focused on the use of the projects in individual teaching rather than as a distributable curriculum project. Although the lack of money to pay qualified graduate students explained part of this, the fact that staff were occupied during the no-cost extension year with producing an efolio project based on the open source portfolio initiative (http://www.osportfolio.org/) also accounted for inattention to the curriculum project. In sum, these factors meant there was no money to pay for time and resources to devote to JC projects, and there was no time to devote to marketing or seeking further funding for developing the JC. The challenges of marketing and support for continued revision and improvement of the projects after the grant, not in the typical faculty purview, are substantial and were not specifically addressed in the original grant. Providing for these activities once the projects are produced is one possible strategy for making this type of project achieve its goal of sustaining faculty involvement in improving and extending their competencies with technology-based curriculum resources. Despite the downscaling of the Judgment Curriculum resulting from a shift in focus from a distributable curriculum resource as originally conceived to a resource used in teaching by individual participants, the projects continue to have life and the option to create a viable web-based curriculum resource is not foreclosed. In fact, the extra time sponsored by the no-cost extension led to the development of one new project.

During the project extension year 2004-05, the project director and co-author of this paper, finally had time to pursue a JC project related to technology. Titled, "Techne - What is Technology?" the project is comprised of an introductory series of interviews with middle school age children where they respond to the question: what is technology?, an animated video program presenting ideas 
about the meaning of technology derived from the ancient story of Prometheus Bound, and a two level Web Quest. These resources are now ready for field-testing and we are now seeking funding for additional testing of JC units with students and teachers, for refining existing projects, for developing new ones, and for exploration of the $\mathrm{JC}$ lessons and units as products for use by other teachers. The JC prototype is at http://emt.bu.edu/judgmentCurriculum/. The Techne project is at http://emt.bu.edu/techne.

\section{Some results and conclusions}

A goal of the BU-PT3 project was that "work on the design and classroom use of units of this curriculum will become a core part of SED's teacher preparation programs thus becoming a vehicle through which the grant will be sustained after the years of direct funding are past" (Whittier \& Steiner, 2001). This goal was directed in part toward the development and use of JC units by teacher candidates in their student teaching. Now, however, achieving this goal appears unrealistic, as assigning our student teachers to develop technology-based lessons on judgment for use in their student teaching has proved problematic for a number of reasons.

- First, finding field placements and skilled cooperating teachers is a complex task, often being resolved very close to the time the student teacher is to begin.

- Second, the variety of technology expertise possessed by the cooperating teachers, not currently a criterion for placement, as well as their varying degree of receptiveness to the project means that the placement is unreliable as a context for deploying technology-based lessons on judgment.

- Third, the many demands placed on the student teachers simply to manage the class and teach what is required as directed by the cooperating teacher and state curriculum standards and testing has proved far too demanding a context on which to impose developing the JC.

In this regard, the real promise appears to be in keeping the faculty involved in producing and utilizing class projects and in preparation of lessons that can be used with future pre-service teachers and in assigning their students, tomorrow's teachers, to develop their own technology-infused class projects for use in methods and other university courses. However, sustained growth in this area may require ongoing support by qualified graduate students such as those who comprised our ETG. This suggests a model of school organization that includes ETG or instructional technology specialists who are paid staff and whose responsibilities include working in partnership with faculty to produce and continuously improve technology-based curriculum resources.

Another challenge to making a viable resource of the Judgment Curriculum is to find reasonable coherence among the variety of lessons produced by participating faculty. Finding the right balance between the need for consistency in a coherent software product on one hand and the wide variety of $\mathrm{JC}$ lessons developed by different faculty, in different disciplines, and for different levels of learners on the other, is indeed a challenge. Furthermore, it is unclear how work on the JC projects will continue now that the funding has ended and the context and community generated by the grant is no longer present. What will motivate faculty to take the time to continue with JC projects is an important question. So far, the only partial answer is that without funding for the curriculum project, only their teaching remains to motivate continued involvement with the JC lessons.

The Judgment Curriculum was initially envisioned as a "multimedia, Web-based architecture [that] will allow improved dissemination, portability, and revision as well as opportunities for feedback for both teachers and students." Clearly, it is easier to disseminate and revise work on the Web than any previous method and the current design of the JC interface will allow for easy communication and feedback. However, making the JC fully functional and accessible on the web is still ahead as integrating the various projects into a coherent and overarching interface and architecture is still a problem. Readers may view some project presentations at http://emt.bu.edu/judgmentCurriculum/. The Techne project is at http://emt.bu.edu/techne. See an example of the prototype in Figure 1.

[Insert Figure 1] 
The quest for the judgment curriculum began with big philosophical questions such as: what is truth? what is beauty?, what is justice?, what is democracy?, what is good?, and even, what is technology? We proposed that developing technology-based resources to stimulate thinking about these or other questions related to judgment in their own disciplines would sustain faculty use of technology as well as develop an innovative curriculum resource. It did this but mainly in the context of each faculty's own teaching and not in the context of a curriculum project. Further data on the use of the JC projects in individual teaching comes from an April 2004 survey of participating faculty and provides a sense of the impact of the BU-PT3 program. Faculty reported that for the 2003-04 academic year nine percent of all their students (78 of 867) had been involved in producing JC resources. The data on student use of JC resources is less encouraging as only three of 867 actually used a JC resource in their student teaching. The most encouraging data comes from asking faculty if they assigned their students to produce technology-infused lessons because of their training received in the BU-PT3 project. Faculty reported that they assigned 577 of 867 , or $66 \%$, of their students to produce technology-infused lessons. One qualification of this data is that some participating faculty also reported that they assigned their students to produce technology-infused lessons before PT3. These faculty taught $41 \%$ of the students (232 of 867 ) and hence, we can report an absolute growth of only $23 \%$. Despite that lower figure, faculty who required technology-based work before BU-PT3 report that their assignments have grown in depth and complexity and they feel more confident in their ability to assign and assess students' work with technology.

The BU-PT3 project has had a significant impact on both faculty use and their student's use of technology integrated curriculum resources even though we are now back to "each tub on its own bottom" and the community developed as part of the grant has dissipated. Further, without the stimulus of a grant and collaborative curriculum project, sustaining and improving the technology expertise of each faculty has reverted to individual challenge. Now the question is: does the JC have a future, and, can it be reinvigorated to sustain faculty development and the carefully nurtured community of learners? Despite the return to individualism, we have not given up on the JC as we seek funding for marketing and continued development of the curriculum project. We look forward to reporting further on the impact of the Judgment Curriculum on learning and on sustaining faculty development in appropriately integrating technology into teaching both as a curriculum project and in individual teaching.

\section{Acknowledgment}

This work has been supported by US DOE PT3 grant P342A-010121.

\section{References}

Becker, H., (2000). Findings from the teaching, learning, and computing survey: Is Larry Cuban Right? http://www.crito.uci.edu/tlc/html/findings.html

CEO Forum on Educational and Technology (1997) From Pillars to Progress, Washington D.C., CEO Forum [on-line] [www.ceoforum.org/reports.cfm] (April 2003).

CEO Forum on Educational and Technology (1999) Professional Development: $A$ Link to Better Learning, Washington D.C., CEO Forum [on-line] [www.ceoforum.org/reports.cfm] (April 2003)

CEO Forum on Educational and Technology (2000a) Teacher Preparation STaR Chart. A Self-Assessment Tool for Colleges of Education, Washington D.C., CEO Forum. [on-line] [www.ceoforum.org/reports.cfm] (April 2003).

CEO Forum on Educational and Technology (2000b) The power of Digital Learning. Integrating Digital Content, Washington D.C., CEO Forum [on-line] [www.ceoforum.org/reports.cfm] (April 2003)

CEO Forum on Educational and Technology (2001) Key Building Blocks for Student Achievement in the 21 st Century. Washington D.C., CEO Forum [on-line] [www.ceoforum.org/reports.cfm] (April 2003) 
CEO Forum on Educational and Technology (2003) Assessment, Alignment, Accountability, Access, Analysis, Washington D.C.,. [on-line] [www.ceoforum.org/reports.cfm].

Cuban, L. (1986) Teachers and Machines. The Classroom Use of Technology Since 1920, New York, N.Y., Teachers College Press.

Cuban, L. (2001) Oversold and Overused. Computers in the Classroom, Cambridge, Harvard University Press.

Davis, N. (2003). Technology in Teacher Education in the USA: What makes for sustainable good practice? Technology, Pedagogy and Education, Vol 12, No. 1, pp. 59-84.

Davis, N., Kirkman, C., Tearle, P., Taylor, C., \& Wright, B., (1996). Developing Teachers and Their Institutions for IT in Education: An Integrated Approach. Journal of Technology and Teacher Education (4)1 3-18.

Hinostroza, Pedro, \& Laval (n. d.). Enlaces: The Chilean ICT Experience in Education. Retrieved January 15, 2006. http://www.mirandanet.ac.uk/ftp/enlaces.pdf

Kozma, R. (Editor) (2003). Technology Innovation, and Educational Change: A Global Perspective. ISTE. Eugene (OR).

Lara, S. \& Whittier, D. (2004). Preparing Teachers, Student Teachers, and Schools for the 21st Century: Review of Recent Reports in the U.S. ED-MEDIA Conference, Lugano, June.

OTA (1995, April) Teachers and Technology: Making the Connection. Office of Technology Assessment, OTA-EHT-616. Washington, D.C.: U.S. Government Printing Office. [on-line] [http://www.wws.princeton.edu/ ota/disk1/1995/9541.html] (April, 2003)

Potashnik, M., (1996). Chile's learning network. Education and Technology Series 1(2)Retrieved January 15, $2006.2 \mathrm{http}: / / \mathrm{www}-$ wds.worldbank.org/servlet/WDSContentServer/WDSP/IB/1996/01/01/000009265_398042 9110709/Rendered/PDF/multi_page.pdf

Rowand, C. (2000). Teachers' use of computers and the Internet in public schools. Education Statistics Quarterly: Elementary and Secondary Education. Summer 2000. (http://nces.ed.gov/pubs2000/quarterly/summer/3elem/q3-2.html).

Saettler, P. (1990) The Evolution of American Educational Technology, Colorado, Libraries Unlimited, Inc.

Technology Counts, (1997), (1998), (1999), (2001), (2002), available online at URL: http://www.edweek.org/sreports/special_reports_full_list.html

TERC (2003). Unpublished Evaluation Reports. Cambridge, Massachusetts.

The Campus Computing Project (1995-2003). http://www.campuscomputing.net/

UNESCO (2002). Information and Communication Technologies in Teacher Education. A Planning Guide. Division of Higher Education. UNESCO. Paris (France)

UNESCO (2003). Teacher Training on ICT Use in Education in Asia and the Pacific: Overview from Selected Countries. UNESCO. Bangkok (Thailand)

UNESCO (2005). Experiencias de formación docente utilizando tecnologías de información y comunicación. Estudios realizados en Bolivia, Chile, Colombia, Ecuador, México, Panamá, Paraguay y Perú. UNESCO. Oficina Regional de Educación para América Latina y el Caribe. Santiago (Chile).

US DOE, OERI, (2000). The first year implementation of the technology literacy challenge fund in five states" http://www.ed.gov/pubs/TLCFFirstYearReport/index.html. 
WBEC (2000) The Power of the Internet for learning: Moving from promise to practice. Report of the Web-Based Education Commission to the President and the Congress of the United States. Washington, D.C. [on-line] [www.ed.gov/offices/AC/WBEC/FinalReport/] (April 2003)

Weizenbaum, Joseph (1976). Computer power and human reason: From judgment to calculation, W. H. Freeman \& Co., San Francisco.

Whittier, D. \& Steiner, D., (2001). Boston University, School of Education, Preparing Tomorrow's Teachers to use Technology (PT3) Grant Proposal. Unpublished Manuscript.

Whittier, D. (2004). Can Faculty Expertise be Sustained with Curriculum Development? Technology and the Judgment Curriculum Project. In ED-MEDIA Conference, Lugano, June.

Whittier, D., \& Lara, S., (2003a). Preparing Tomorrow's Teachers to Use Technology (PT3) at Boston University through faculty development. Estudios Sobre Educacion, N5, pp 47-60.

Whittier, D., \& Lara, S., (2003b). Preparing Tomorrow's Teachers to Use Technology (PT3) at Boston University: Assessment of the Initial Two Years of the Project. In mICTE2003 Conference, Badajoz (Spain), December. 


\begin{tabular}{|c|c|c|c|}
\hline Aim & Objectives & Methodology & Year \\
\hline \multirow{4}{*}{$\begin{array}{l}\text { 1. To infuse high } \\
\text { quality } \\
\text { educational } \\
\text { technology into all } \\
\text { aspects of SED } \\
\text { student teacher } \\
\text { preparation } \\
\text { program }\end{array}$} & $\begin{array}{l}\text { 1. The faculty will successfully update and refine } \\
\text { their own pedagogical skills to take advantage } \\
\text { of new technologies for diverse student } \\
\text { populations. }\end{array}$ & \multirow{4}{*}{$\begin{array}{l}\text { Faculty Training } \\
\text { Program: } \\
\text { - A course on the } \\
\text { web: Courselnfo } \\
\text { - Educational } \\
\text { Technology } \\
\text { Group (ETG) } \\
\text { - Training Sessions } \\
\text { and Roundtable }\end{array}$} & 2001-02 \\
\hline & $\begin{array}{l}\text { 2. The faculty will evaluate their courses and } \\
\text { begin the process of infusing technology into } \\
\text { their curricula allowing them to model such } \\
\text { practices to their students. }\end{array}$ & & and \\
\hline & $\begin{array}{l}\text { 3. The faculty will revise the academic content of } \\
\text { their methods courses to ensure that their use } \\
\text { of educational technology is matched to the } \\
\text { best available scholarly content. }\end{array}$ & & \\
\hline & $\begin{array}{l}\text { 4. Students will acquire skills in using educational } \\
\text { technology }\end{array}$ & & \\
\hline \multirow{2}{*}{$\begin{array}{l}\text { 2. To sustain the } \\
\text { infusion of } \\
\text { educational } \\
\text { technology } \\
\text { achieved during } \\
\text { the grant period } \\
\text { beyond the } \\
\text { withdrawal of the } \\
\text { grant funding }\end{array}$} & $\begin{array}{l}\text { 1. Implementation of a full program of integrated } \\
\text { technology rich and academically rigorous } \\
\text { teacher preparation courses in SED. }\end{array}$ & \multirow[b]{2}{*}{$\begin{array}{l}\text { The Judgment } \\
\text { Curiculum }\end{array}$} & \multirow[b]{2}{*}{ 2003-04 } \\
\hline & $\begin{array}{l}\text { 2. Long term support for curriculum and } \\
\text { technology integration at SED and its } \\
\text { alternative teacher preparation programs } \\
\text { through provision of a high quality, Web-based } \\
\text { academic curriculum designed for use in } \\
\text { schools }\end{array}$ & & \\
\hline
\end{tabular}

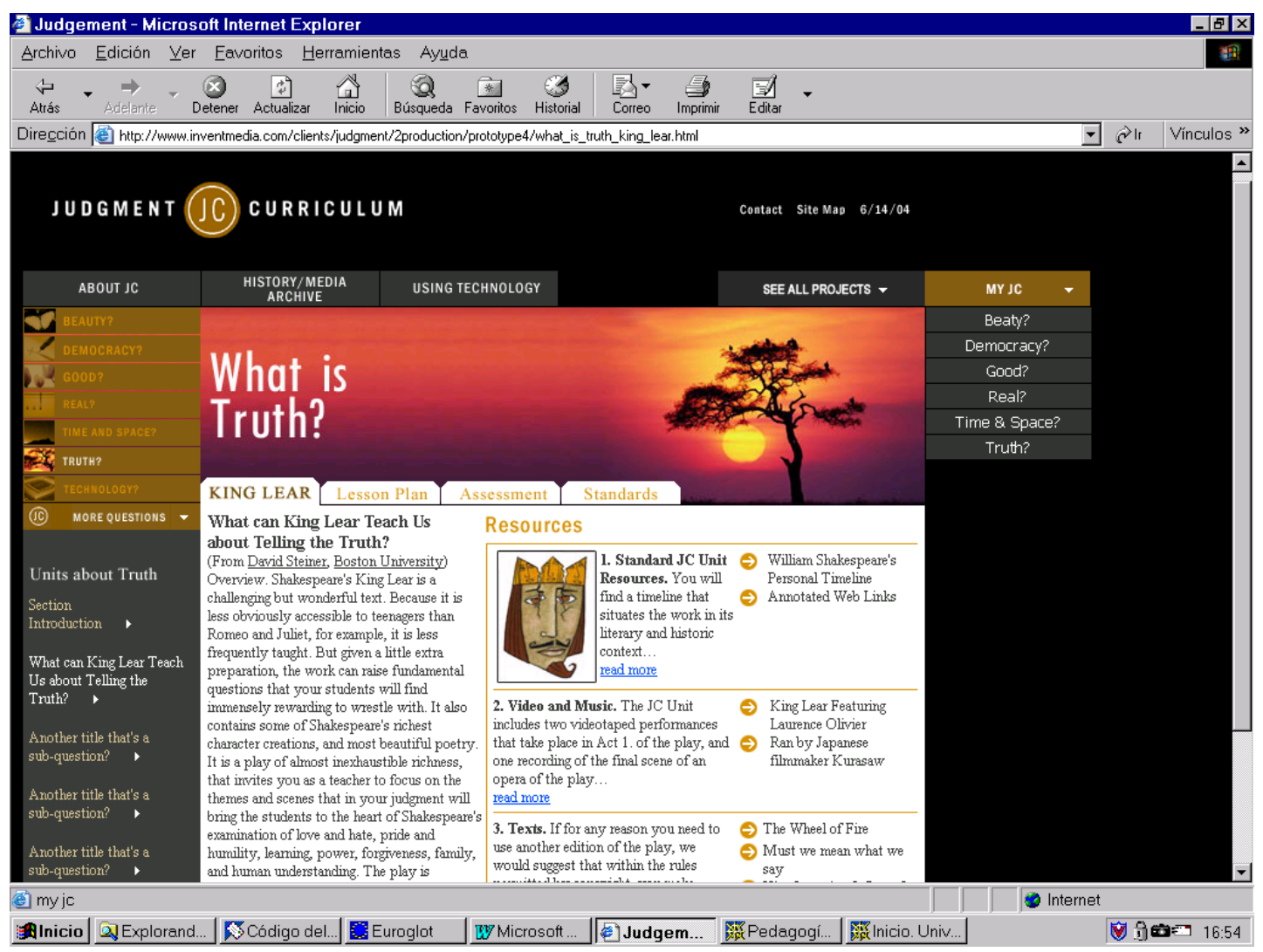

Figure 1. The Judgment Curriculum Prototype 